\title{
EFFECT OF SUPPLIER RELATIONSHIP MANAGEMENT ON THE EFFECTIVENESS OF SUPPLY CHAIN MANAGEMENT IN THE KENYA PUBLIC SECTOR.
}

\author{
Ondieki John Nyamasege ${ }^{1}$ and Oteki Evans Biraori ${ }^{2}$ \\ ${ }^{1} \mathrm{PhD}$ student, Jomo Kenyatta University of Agriculture \& Technology, Nairobi, Kenya. \\ ${ }^{2} \mathrm{PhD}$ student, Jomo Kenyatta University of Agriculture \& Technology, Nairobi, Kenya.
}

\begin{abstract}
The main objective of the study was to assess factors affecting the effectiveness of supply chain management practices in Kenyan public sector case of Ministry of Finance with the aim of assessing the effect of supplier relationship on the effectiveness of supply chain management practices. The study adopted a descriptive case research design with study population of 120 management staff working at the Ministry of finances' procurement, finance and administration departments from which a sample size of 60 respondents was drawn. Questionnaires were used for data collection and descriptive statistics data analysis method was applied to analyze data aided by Statistical Package for Social Sciences. The study identified that lack of supplier relationship management strategies lowered the effectiveness of supply chain management functions. The study recommended application of supplier collaboration strategies.
\end{abstract}

\section{KEYWORDS}

Procurement, Supplier and Customer Relationship, Supply Chain Management

\section{INTRODUCTION}

Supplier relationship management entails determining how company buyers interact with suppliers. It is a mirror image of customer relationship management. Just as a company needs to develop relationships with its customers, it needs to foster relationships with its suppliers to ensure quality goods and services, timely and assured deliveries and information flow to assist both organizations in planning. At the strategic level, the output of the process is an understanding of the levels of relationships the firm will maintain, and the process for segmenting the suppliers and working with them to develop appropriate relationships. Once the process team determines the criteria for categorization of suppliers and the levels of customization, the operational supplier relationship management process develops and manages the relationship. Relationships can take the form of supplier captive or buyer captive. Supplier applies when the supplier has less chances of changing the buyer either because of the supplier having invested a lot of resources to produce a particular product to a given firm and hence moving will be a loss, a case where a supplier has only one or a few clients to deliver to. Buyer captive arises when the buyer has one source to buy from such as when there is only one supplier or manufacturer of product. In both cases, relationships should be a win-win to both for both firms to reduce costs and share profits.

DOI: $10.5121 /$ ijmvsc.2015.6103 


\subsection{Statement of the Problem}

In Kenya, over seventy percent $(70 \%)$ of public sector organizations experience supply chain management challenges and this negatively affects effective delivery of services [24]. The ministry of finance was ranked $7^{\text {th }}$ in performance, according to the performance contracting secretariat report. As a strategic ministry in charge of financial policy formulation and implementation in public sector, the ministry was supposed to do better. A case in point is the De La Rue currency printing sager. When a new government was formed in 2003, the then minister for finance cancelled an exclusive 10-year contracts to print Kenyan bank notes because it was allegedly hurriedly awarded. Instead, CBK floated an international tender for printing of 400 million units of new generation currency. The competitive bidding process could not succeed since De La Rue had already established a long working relationship with the CBK. The ministry of finance tabled a policy paper before the cabinet proposing to give De La Rue an exclusive currency printing contract for 10 years and then later acquire $40 \%$ of the company shareholding. Many financial experts, more especially in the private sector felt that the contract was skewed towards De La Rue. The matter is a subject to investigation by the public accounts committee. It casts aspersions on the supply chain efficacy of the ministry.

In spite of having many SCM studies undertaken by Goldstein[29], Harmon[31], Harrison[32], Peters[15], Martin[24], Edward[45] and Clerk[13], none of the studies have drawn much emphasis on how public sector organizations should improve the effectiveness of the supply chain management practices. Hence this has created a knowledge gap amongst procurement and logistics practitioners in public sector organizations.

\section{LITERATURE REVIEW}

Lee [39] affirmed that SRM is a discipline of working collaboratively with those suppliers that are vital to the success of your organization to maximize the potential value of that relationship. SRM is about developing two-way, mutually beneficial relationships with your most strategic supply partners that deliver greater levels of innovation and competitive advantage than could be achieved by operating independently.

Peters [55] argued that SRM managers should be responsible for managing no more than three supplier relationships, in order to devote sufficient time to each. Staff involved in SRM activities will have a good combination of commercial, technical and interpersonal skills. Commercial acumen, market knowledge, analytical abilities and project management expertise are important. But "softer" skills around communication, listening, influencing and managing change are critical to developing strong and trusting working relations. SRM managers understand their suppliers' business and strategic goals and are able to see issues from the supplier's point of view, while balancing this with their own organization's requirements and priorities.

Cooper [14] concurred that SRM includes both business practices and software and is part of the information flow component of supply chain management (SCM). SRM practices create a common frame of reference to enable effective communication between an enterprise and suppliers who may use quite different business practices and terminology. As a result, SRM increases the efficiency of processes associated with acquiring goods and services, managing inventory, and processing materials. According to Ansari [1], the use of SRM software can lead to lower production costs and a higher quality, but lower priced end product. 


\subsection{Objective}

The main factors that affect effectiveness of SCM can be broadly classified into supplier relationship, inventory management, information technology, training and distribution. Therefore, the study identifies factors that influence effectiveness of the supply chain classifying them as enablers and results. Enablers will be the factors that enable an organization to achieve or to improve the supply chain effectiveness.

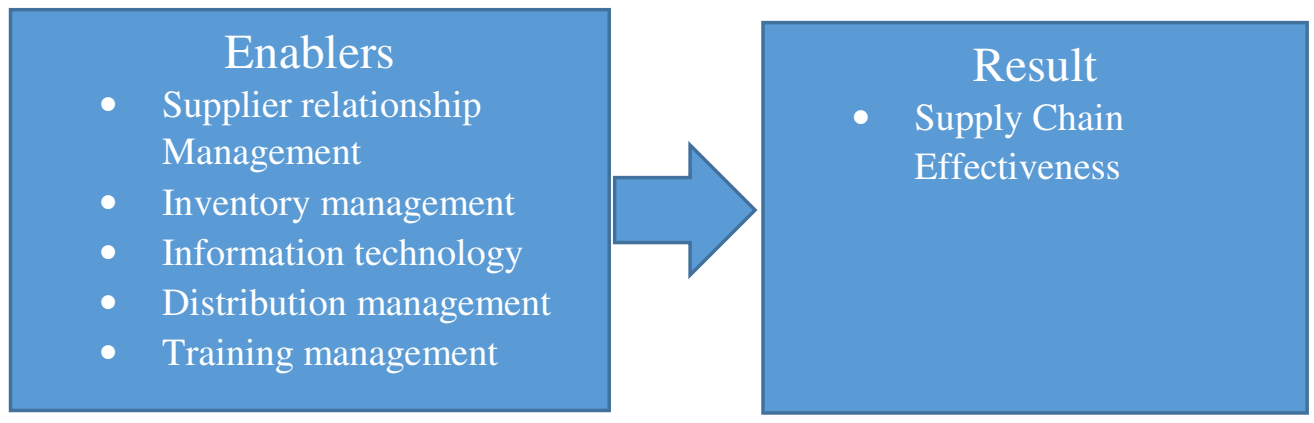

Figure 1. Relationship between Enablers and Result

This paper considers one of the enablers namely the effect of supplier relationship management on the effectiveness of supply chain management practices in the ministry of finance. Further, the study also includes the variables that create supplier relationship management such as collaboration, development, quality of goods and customer service.

\subsubsection{Effective Supply Chain Management}

Supply chain effectiveness is the relationship between actual and planned performance. As the strategic significance of purchasing increases, performance measures became more qualitative and judgmental in character - more effectiveness-oriented (non-financial factors). These may include internal environmental factors to purchasing function such as supplier management, communication both internally and externally, performance of purchasing tasks, the level of participation in decision making, stage of company development, professionalism, attitude, ethics, culture, etc. of purchasing staff

\subsubsection{Supplier Relationship Management}

Browne [12] contended that supplier relationship management is a comprehensive approach to managing an enterprise's interactions with the organizations that supply the goods and services it uses. The goal of supplier relationship management (SRM) is to streamline and make more effective the processes between an enterprise and its suppliers just as customer relationship management (CRM) is intended to streamline and make more effective the processes between an enterprise and its customers.

Supplier involvement in product development allows firm to make better use of their supplier's capabilities and technology to deliver competitive products. Coordinating operational activities through joint planning also results inventory reduction smoothing production, improve product quality, and lead time reductions argues that integration is an effective strategy in reducing with suppliers throughout the product lifecycle is an effective strategy in reducing supply uncertainty [33]. 


\section{RESEARCH METHODOLOGY}

The study adopted a descriptive case research design. The study gathered both quantitative and qualitative data that described the nature and characteristics of factors affecting the effectiveness of supply chain management practices in the ministry of finance. The study considered this design appropriate since it facilitated towards gathering of reliable data that gave a true picture of factors hindering effectiveness of supply chain management practices in the ministry of finance. The study population comprised of 120 management staff and 60 respondents selected randomly. Primary data was gathered through a semi structured questionnaire. Analysis was done by the Statistical Package for Social Sciences.

\section{RESEARCH FINDINGS AND DISCUSSION 4.1 Supplier Relationship Management Challenges}

The study sought to establish if the organization faced supplier relationship management challenges and the obtained findings were presented in table 4.1. Majority (83\%) of the respondents indicated that the organization faced supplier relationship management challenges. The respondents who disagreed with majority opinion were only (17\%) of the total response rate. The respondents affirmed that the organization lacked a comprehensive approach for managing interactions with suppliers and this affected realization of increased effectiveness on supply chain processes between the organization and the suppliers.

Table 4.1 Supplier Relationship Management Challenges.

\begin{tabular}{ccc}
\hline Response & Frequency & Percentage \\
\hline Yes & 40 & $83 \%$ \\
No & 8 & $17 \%$ \\
Total & $\mathbf{4 8}$ & $\mathbf{1 0 0 \%}$ \\
\hline
\end{tabular}

4.2 Effect of supplier relationship management on the effectiveness of supply chain management practices.

The study aimed to find out if supplier relationship management affected the effectiveness of supply chain management practices in the organization. The findings were presented in table 4.2. Majority (90\%) of the respondents felt that supplier relationship management affected the effectiveness of supply chain management practices in the organization and only $10 \%$ of the respondents who were to the opinion that supplier relationship management did not affect the effectiveness of supply chain management practices in the organization.

Table 4.2 Effect of supplier relationship management on the effectiveness of SCM

\begin{tabular}{ccc}
\hline Response & Frequency & Percentage \\
\hline Yes & 43 & $90 \%$ \\
No & 5 & $10 \%$ \\
Total & $\mathbf{4 8}$ & $\mathbf{1 0 0 \%}$ \\
\hline
\end{tabular}




\subsection{How supplier relationship affect effectiveness of SCM}

Table 4.3 presents that supplier collaboration has a mean of 4.41 indicating that supplier collaboration affected the effectiveness of supply chain management practices to a large extent, supplier development scored a mean of 4.12 indicating that supplier development affected the effectiveness of supply chain management practices to a large extent, Quality of goods and services recorded a mean of 4.45 indicating that the quality of goods and services delivered by suppliers affected the effectiveness of supply chain management practices to a large extent. Finally, customer service scored a mean of 4.08 and this demonstrates that customer service affected the effectiveness of supply chain management practices to a large extent. It's clear that all the supplier relationship activities scored an average mean of 4.08 and above and this demonstrates that supplier, collaboration, supplier development, quality of goods and services and customer care service affected the effectiveness of supply chain management practices to a large extent. The table further indicates that the variance and standard deviation on all the factors was almost equal with only customer service recording a slight difference. This indicated that the respondents answered the questions in the same way and gave reliable and accurate answers on all the supplier relationship activities. This contended with findings by Joppe [36], that a narrow difference between variance and standard deviation on respondent's answers is clear indication of reliability and accuracy of the respondents answers on issues surrounding the research problem.

Table 4.3. Extent to which supplier relationship activities affect the effectiveness of supply chain management practices in the organization

\begin{tabular}{lllll}
\hline $\begin{array}{l}\text { Supplier relationship } \\
\text { activities }\end{array}$ & $\mathrm{N}$ & Mean & Std. Deviation & Variance \\
\hline Supplier collaboration & 48 & 4.4167 & .96389 & .929 \\
Supplier development & 48 & 4.1250 & .91384 & .835 \\
Quality goods and & 48 & 4.4583 & .74258 & .551 \\
services & & & & \\
Customer service & 48 & 4.0833 & 1.12672 & 1.270 \\
Valid N (listwise) & 48 & & & \\
\hline
\end{tabular}

\subsection{Relationship between supply chain management effectiveness and supplier relationship management.}

The study subjected the gathered data under each research variable to inferential statistical tool, thus correlation analysis. Correlation analysis is used to determine how strongly the scores of two variables are associated or correlated with each other. Table 4.4 shows that Supplier relationship management had a strong positive correlation with effectiveness of SCM practices $(r=0.845)$. This correlation was found to be statistically significant at 0.01 significance level ( $\mathrm{p}$-value $=$ $0.000)$. 
Table 4.4 Correlation Analysis Results

\begin{tabular}{|c|c|c|c|}
\hline Variables & & $\begin{array}{l}\text { Supply chain } \\
\text { management }\end{array}$ & $\begin{array}{l}\text { Supplier relationship } \\
\text { management }\end{array}$ \\
\hline \multirow{3}{*}{$\begin{array}{l}\text { Supply chain } \\
\text { management }\end{array}$} & $\begin{array}{l}\text { Pearson } \\
\text { Correlation }\end{array}$ & 1 & $.845^{* *}$ \\
\hline & Sig. (2-tailed) & & 0 \\
\hline & $\mathrm{N}$ & 48 & 48 \\
\hline \multirow{3}{*}{$\begin{array}{l}\text { Supplier relationship } \\
\text { management }\end{array}$} & $\begin{array}{l}\text { Pearson } \\
\text { Correlation }\end{array}$ & $.845^{* *}$ & 1 \\
\hline & Sig. (2-tailed) & 0 & \\
\hline & $\mathrm{N}$ & 48 & 48 \\
\hline
\end{tabular}

\section{SUMMARY, CONCLUSIONS AND RECOMMENDATIONS. 5.1 Supplier Relationship Management}

The study findings indicate that supplier relationship management greatly determine the effectiveness of supply chain management practices in the ministry of finance. Supplier collaboration and development enhances effectiveness in SCM in acquiring goods and services. The study noted that lack of a comprehensive approach for managing interactions with suppliers affected realization of increased effectiveness on supply chain processes between an organization and the suppliers.

\subsection{Conclusion}

The effectiveness of supply chain management practices in the ministry of finance depended on application of modern supplier relationship management strategies. Supplier relationship activities play important role where players willingly share risks and rewards and maintain relationship on long term basis.

\subsection{Recommendations}

To manage supplier relationship management, the ministry should intensify centralization of common user items. The organization should create a data base on supplier activities such as delivery schedules, complaints, quality management processes. The procurement managers in organization should increase the level of interaction with suppliers. The interaction should involve efficiently providing suppliers with expectations of how the communications and flow of products/services are to be provided.

\subsection{Suggestions for Further Studies}

Further studies is encouraged to explore the effect of procurement regulations, quality standards and sourcing strategies on SCM effectiveness and also help in establishing supply chain management best practices in the public sector organisations.

\section{REFERENCES}

1 Abraham k. (2009). Managing Human Resources, Fourth Edition, Prentice Hall

2 Ansari s. (2009). Purchasing and Supply Management, 6th edition, McGraw-Hill

3 Athur, P. (2007). Supply chain management", Journal of the Academy of Marketing Science, Vol. 38

4 Armstrong.(2010).Human resource management. Third edition. Kogan Page. USA.Washington, 
International Journal of Managing Value and Supply Chains (IJMVSC) Vol. 6, No. 1, March 2015

5 Baden, L.(2004). Supply chain management", Journal of the Academy of Marketing Science, Vol. 28

6 Bill, L. (2009). Supplier Management. Third Edition; Pearson Publisher

7 Boyer, S.(2010).Research opportunities in supply chain management", Journal of the Academy of Marketing Science, Vol. 38

8 Bogdan, J. (2003), Understanding Conceptual Framework; Second edition. Kogan Page Publishers

9 Bowersok, P.( 2000). Purchasing and Supply Management, 6th edition, McGraw-Hill.

10 Braxton, P. (2008). Supply chain Management, 4th edition, McGraw- Hill.Uk.London

11 Bren, M. (2009). European Logistics: Markets, Management and Strategy. First Edition.

Blackwell. Oxford, London

12 Browne, M. (2004). European Logistics: Markets, Management and Strategy. FirstEdition. Blackwell. Oxford,

13 Clerk, S. (2003). Supply chain management", Journal of the Academy of Marketing Science, Vol. 38

14 Cooper, J. (2004). Supply Chain Management Practices. Second Edition. Pearson Publishers

15 Cooper, R.D, \& Schindler, P. (2003). Business Research Methods. Third Edition. New York: McGraw- Hill.

16 Coote, B. (2002). The Trade Trap: Poverty and Global Commodity Markets, Oxfam, Oxford.

17 Cox, C. (2003), Chocolate Unwrapped: The Politics of Pleasure, The Women's Environmental Network, London.

18 Coellho, A. (2003).Channel performance in single vs multiple channel strategies, International Journal of Retail \& Distribution Management, Vol. 31

19 Caines, C. (2005). Implementation of supply chain management and its impact on the Value of firms", Supply Chain Management: An International Journal, Vol. 10

20 Cravens, C. (2006). Supply chain management and its impact on the Value of firms", Supply Chain Management: An International Journal, Vol. 22

21 Dempsey,B. (2003).Research Methods, Fourth Edition, Pearson Publishers

22 Easingwood,G. (2007). Supplier Management. Third Edition; Pearson Publisher

23 Emberson,C. (2006). Supply chain management. Supply Chain Management Journal, Vol. 32

24 Edward,C.(2008). Supply Chain Management International Journal, Vol. 44

25 Cravens, C. (2006). Supply chain management and its impact on the Value of firms", Supply Chain Management: An International Journal, Vol. 22

26 Gartona,L. (2006). Purchasing \& Supply Management 4th edition. Pearson Publishers

27 Gerald, C.(2006). Purchasing \& Supply Management 4th edition. Pearson Publishers

28 Godsell, S. (2006), "Use of structural equation modeling in operations management research: looking back and forward", Journal of Operations Management, Vol. 33

29 Goldstein, S. (2006), "Use of structural equation modeling in operations management research: looking back and forward", Journal of Operations Management, Vol. 24

30 Grant, S. (2006), "Use of structural equation modeling in operations management research: looking back and forward", Journal of Operations Management, Vol. 33

31 Harmon, T. (2010). Research opportunities in supply chain management. Journal of the Academy of Marketing Science, Vol. 38

32 Harrison, A. (2006).Supply chain management: theory, practice and future challenges. International Journal of Operations \& Production Management, Vol. 26

33 Hanfield, A. (2001).Supply chain management: theory, practice and future challenges. International Journal of Operations \& Production Management, Vol. 17

34 Hayes,P. et al. (2005). Business Research Methods. Third Edition. New York: McGraw- Hill.

35 Heikilla, A. (2002).Supply chain management: theory, practice and future challenges. International Journal of Operations \& Production Management, Vol. 33

36 Joppe, C.R. (2000). Elements of Education and Social Science Research Methods. Second Education,Kanezja Publishers.India

37 Kothari, C.R. (2003). Research methodology: Methods \& techniques. First Edition, New Age International Publishers

38 Lambert.L. (2005). Supply Chain Management. First Edition; Pearson publishers

39 Lee, S. (2002). Supplies and Materials Management, third edition. Mc Donald and Evans Limited, Eastover, Plymouth 
International Journal of Managing Value and Supply Chains (IJMVSC) Vol. 6, No. 1, March 2015

40 Leeders, M. (2007). Logistics and Supply Management. First Edition. Pitman Publishing.

41 Levi, S. (2001). Supplies and Materials Management, first edition. Mc Donald and Evans Limited, Eastover, Plymouth

42 Lysons K., (2008). Purchasing M \& F .5th Edition. Pitman Publishers

43 Lyman, S. (2002).Supply chain management: a strategic perspective", International Journal Operations \& Production Management, Vol. 22

44 Martinez, A. (2009).Purchasing and Supply Management, 6th edition, McGraw-Hill.

45 Martin, A. (2006).Supply chain management: theory, practice and future challenges. International Journal of Operations \& Production Management, Vol. 27

46 Mentzer, P. (2004). Inter-organizational cooperation and environmental change: Moderating effects between flexibility and innovation performance", British Journal of Management, Vol. 20

47 Mugenda and Mugenda (1999) Research Methods: third edition. Jomo Kenyatta Publishers.

48 Morris, S. (2001) Data analysis methods: third edition; Pearson Publishers

49 Moore, G. (2008). Business Research Methods. Third Edition. New York: McGraw- Hill

50 Mitra, S. (2008).Supply chain integration and shareholder value: evidence from consortium-based industry exchanges", Journal of Operations Management, Vol. 26.

51 Miller, P. (2005). Purchasing Principle \& Techniques. Third Edition. Prentice Hall

52 Orodho, C.R. (2003). Elements of Education and Social Science Research Methods. Second Education,Kanezja Publishers

53 Patterson, J. (2005). Implementation of supply chain management and its impact on the Value of firms", Supply Chain Management: An International Journal, Vol. 10

54 Paul, W. (2004). Procurement Challenges, 1st Edition; East Africa Press

55 Peters, M. (2004).Logistics Management. Journal of Supply Chain Management. Volume 14.

56 Porter, M. (2005).Logistics Management. Journal of Supply Chain Management. Volume 14.

57 Pritchard, V. (2005). Supplies and Materials Management, third edition. Pearson Publishers

58 Reichheld, L. (2000). Supply chain management challenges International Journal of Operations \& Production Management, Vol. 26

59 Roland, T. (2007) Employee Training. Fourth Edition, Prentice Hall

60 Sherry G.(2005). Seven Steps to Measure Supplier Performance", Quality Progress. Journal of Purchasing Volume 22.

61 Serekan, U. (2003). Research Methods for Business: A Skill Building Approach. (4th Ed.). New York: John Willy \& Sons Inc.

62 Storey, J. (2006).Supply chain management: theory, practice and future Challenges", International Journal of Operations \& Production Management, Vol. 26

63 Stank, F. (2001). Purchasing and Supply Management, 6th edition, McGraw-Hill

64 Scott, C. (2003). Issues of supply chain management practices. Journal of Economics, Volume 24.

65 Stock, J. (2010). Research opportunities in supply chain management", Journal of the Academy of Marketing Science, Vol. 38 No.1, pp.32-41.

66 Tan, K. (2002).Supply chain management: a strategic perspective", International Journal of Operations \& Production Management, Vol. 22

67 Thornton,T. (2001). Supply Chain Management, Second Edition Mc Donald and Evans Limited, Eastover, Plymouth.

68 Tan, L. (2001). Purchasing and Supply Management, 6th Edition.McGraw-Hill.

69 Wisner, J.D. (2002), "Supply chain management: a strategic perspective", International Journal of Operations \& Production Management, Vol. 22

70 White, L. (2001). Logistics and Supply Management. First edition. Pitman Publishing.

71 Whand,F.(2000). Supply Chain Management Networks,Journal of Purchasing.Volume 22

72 William.T. (2007). The Logical Thinking Process: A Systems Approach to Complex Problem Solving. First Edition. ASQ Quality Press.

73 Wright, M. (2002).Supply Chain Network Structures. First Edition.MCgraw-Hill

74 Zinbarg, M. (2005), Research Methods.Second edition. Pearson Publishers.

75 Zhang, F. (2004). Supply Chain Management Networks,Journal of Purchasing.Volume 36 